\title{
PENERAPAN PRINSIP GOOD GOVERNANCE DALAM PELAYANAN PUBLIK DI PUSKESMAS BETUNGAN KOTA BENGKULU
}

\section{APPLICATION OF GOOD GOVERNANCE PRINCIPLES IN PUBLIC SERVICES AT THE BETUNGAN COMMUNITY HEALTH CENTER, BENGKULU CITY}

\author{
Deni Triyanto ${ }^{{ }^{*}}$ \\ Heru Purnawan ${ }^{2}$ \\ Boni Saputra ${ }^{3}$ \\ ${ }^{*}$ Administrasi Publik FISIP \\ Universitas Prof Dr Hazairin SH, \\ Kota Bengkulu, Provinsi \\ Bengkulu, Indonesia \\ ${ }^{2}$ Administrasi Publik FISIP \\ Universitas Prof Dr Hazairin SH \\ Kota Bengkulu, Provinsi \\ Bengkulu, Indonesia \\ 3/lmu Administrasi Negara FIS \\ Universitas Negeri Padang, \\ Provinsi Sumatera Barat, \\ Indonesia \\ *email: \\ dtriyanto992@gmail.com
}

Kata Kunci:

Good Governance

Pelayanan Publik

Puskemas

Kota Bengkulu

\section{Keywords:}

Good Governance

Public Service

Public health center

Bengkulu City

\section{Accepted}

Februari 202I

Published

April 2021

\begin{abstract}
Abstrak
Penerapan prinsip good governance dalam pelayanan publik pada bidang kesehatan dapat terwujud apabila pelayanan di Puskesmas Betungan dilaksanakan secara transparan, responsif, efektif dan efisien waktu (Dwiyanto, 20I5).

Tujuan penelitian ini adalah untuk mendeskripsikan penerapan prinsip good governance dalam pelayanan publik di Puskesmas Betungan Kota Bengkulu, dengan menggunakan metode penelitian deskriptif kualitatif, informan dalam penelitian ini adalah petugas pelayanan, bidan, perawat dan komunitas.

Hasil penelitian mengungkapkan bahwa penerapan good governance dalam pelayanan publik di Puskesmas Betungan Kota Bengkulu sudah cukup maksimal, terlihat prinsip transparansi, responsivitas, prinsip efektifitas dan efisiensi dalam pelayanan kesehatan di Betungan. Puskesmas telah dilaksanakan cukup optimal seperti ketersediaan papan informasi pelayanan, ketersediaan standar pelayanan minimalis, dan adanya monitoring dan evaluasi yang dilakukan oleh Puskesmas untuk meningkatkan pelayanan kesehatan, yang menjadi permasalahan adalah masyarakat pengguna jasa belum mampu mengakses informasi secara luas (berbasis elektronik), belum tersedianya layanan pengaduan online, tidak tersedianya kotak saran dan layanan yang dirasa masyarakat belum mendapatkan pelayanan prima.
\end{abstract}

\begin{abstract}
The application of the principle of good governance in health services can be realized if the service at Betungan Public Health Center is conducted transparently, responsively, effectively and time efficiency (Dwiyanto, 2015).

The purpose of this study is to describe the application of the principles of good governance in health services at the Betungan Health Center in Bengkulu City, with using descriptive qualitative research methods, informants in this study are service officers, midwives, nurses and the community.

The results of the study revealed that the application of good governance in health services at the Betungan Public Health Center in Bengkulu City was quite maximal, it was seen that the principles of transparency, responsiveness, principles of effectiveness and efficiency in health services at the Betungan Health Center had been implemented quite optimally such as the availability of a service information board, the availability of minimalist service standards, and the existence of monitoring and evaluation conducted by Puskesmas to improve health services, the problem is that the service user community has not been able to access information widely (electronically based), the unavailability of online complaint services, the unavailability of suggestion boxes and services that the community feels are still not prime.
\end{abstract}




\section{PENDAHULUAN}

Semangat reformasi telah mewarnai pendayagunaan aparatur pemerintah dengan tuntutan untuk mewujudkan administrasi publik yang mampu mendukung kelancaran dan keterpaduan pelaksanaan tugas dan fungsi penyelenggaraan pemerintahan dan pembangunan, menuntut pelaksanaan Good Governance ini berlaku pada setiap pemerintahan daerah yang sangat diperlukan dalam penyelenggaran otonomi daerah. Konsep good governance pertama kali di perkenalkan oleh United Nation Development Program (UNDP, 1997). (Dwiyanto, 2015) sebab munculnya konsep ini di latarbelakangi oleh tidak terjadinya akuntabilitas dan tranparansi. Artinya banyak negara dunia ketiga ketika diberi bantuan dana tersebut banyak yang tidak tepat sasaran, sehingga negara maju engan memberikan bantuan terhadap negara dunia ketiga karena belum terciptanya sistem birokrasi yang efektif, efesien dan tidak adanya tranparansi, akuntabilitas bantuan dana dari negara maju. Konsekuensinya banyak terjadi Korupsi, Kolusi dan Nepotisme (KKN) yang di lakukan oleh negara ketiga ketika bantuan diberikan oleh negara maju. (Johnson, 20II)

Tujuan reformasi birokrasi yaitu untuk memperbaiki kualitas pelayanan publik di Indonesia, dengan kemajuan teknologi informasi saat ini tuntutan masyarakat terhadap pelayanan kesehatan semakin meningkat, menurut ombusmen Perwakilan Bengkulu bahwa tahun 2017 pengaduan pelayanan kesehehatan di Kota Bengkulu masih menjadi primadona masyarakat, artinya bahwa masih terdapat permasalahan pada pelayanan kesehatan di Kota Bengkulu (Obusman Perwakilan Bengkulu 2018).

Puskesmas di Kota Bengkulu berjumlah 20 unit dengan rincian 17 puskesmas non perawatan dan 3 puskesmas perawatan (rawat inap) yaitu Puskesmas Ratu Agung, Puskesmas Beringin Raya dan Puskesmas Betungan (Dinkes Kota Bengkulu, 2016).
Tata kelola pemerintahan yang baik (good governance) pada pelayanan kesehatan merupakan salah satu prinsip yang harus dipegang teguh dan diimplementasikan oleh seluruh stakeholders terkait bidang pelayanan kesehatan di Kota Bengkulu. Penerapan prinsip good governance tidak dapat diterapkan tanpa dukungan berbagai pihak oleh sebab itu pentingnya kolaborasi kepada SKPD terkait supaya penerapannya dapat berjalan dengan optimal seperti harapan masyarakat Kota Bengkulu sebagai pengguna pelayanan kesehatan di Puskesmas Betungan.

Penelitian terdahulu tentang penerapan good governance telah benyak dilakukan hanya saja yang memfokuskan pada pelayanan kesehatan belum banyak dilakukan salah satunya tentang pelayanan pada Pelayanan kependudukan pada Dinas Kependudukan hasilnya bahwa pelaksanaan Sistem Informasi Administrasi Kependudukan (SIAK) belum berjalan dengan baik dan belum sesuai dengan Permenpan dan RB Nomor 15 Tahun 2014 tentang Pedoman Standar Pelayanan dalam hal sarana dan prasarana, kompetensi pelaksana, dan jumlah pelaksana (Angkat, Kadir, \& Isnaini, 2017), Penelitian terdahulu tentang Sistem Informasi Pelayanan Kesehatan Sebagai Upaya Peningkatan Kinerja E-Government hasilnya bahwa Pelayanan publik saat ini dapat dikatakan belum merata, hanya orang-orang tertentu yang mendapat akses mudah dalam mendapatkan informas (Witanti \& Abdillah, 2018). Berdasarkan penelitian terdahulu bahwa pelayanan publik masih terdapat masalah dan kurang merata, terkhususnya pada sarana seperti sistem informasi pelayanan berbasis teknologi informasi. Berdasarkan permasalahan tersebut tujuan penelitian ini yaitu untuk mendskripsikan penerapan prinsip good governance pada pelayanan kesehatan di Puskesmas Betungan Kota Bengkulu. 


\section{METODOLOGI PENELITIAN}

Metode Penelitian ini yaitu kualitatif dengan pendekatan deskriptif. (Creswell, 2014) Fokus penelitian ini yaitu pada penerapan good governance pada pelayanan kesehatan di Puskesmas Betungan Kota Bengkulu dengan menggunakan 3 (tiga) prinsip yaitu transparansi, responsivitas, efektivitas dan efisiensi. Menggunakan 8 informan yang terdiri dari 2 staf Puskesmas bagian pelayanan kesehatan, Bidan, Perawat dan 4 Masyarakat pengguna pelayanan. Instrumen utama penelitian ini yaitu peneliti sendiri dan didukung oleh instrumen penunjang seperti pedoman wawancara, studi dokumentasi. Manfaat instrumen penunjang yaitu untuk melengkapi kelemahan dari instrumen peneliti sendiri. Teknik analisis data ini menggunakan model miles dan hubermen yaitu : data display, data reduction dan conclution drawing (Sugiyono, 2010).

\section{HASIL DAN PEMBAHASAN}

Secara umum, penelitian ini adalah untuk mendeskripsikan penerapan prinsip good governance dalam pelayanan kesehatan di Puskesmas Betungan Kota Bengkulu berdasarkan prinsip transparansi, responsivitas, efektivitas dan efisiensi.(Teguh, 20II).

\section{A. Penerapan Prinsip Good Governance Dalam Pelayanan Kesehatan di Puskesmas Betungan Kota Bengkulu}

Tercapainya pelayanan kesehatan yang prima bukan saja ditentukan oleh banyaknya jumlah pegawai, tetapi juga ditentukan oleh bagaimana tata kelolah pelayanan seperti transparansi pelayanan, responsivitas pelayanan, efektivitas dan efisiensi pelayanan yang diberikan oleh pegawai kepada masyarakat. Penerapan Prinsip good governance dapat berjalan dapat berjalan dengan baik apabila seluruh aparatur mendukung dalam penerapannya secara maksimal. untuk menganalisis lebih mendalan berikut ini peneliti uraiakan sebagai berikut :

\section{I) Transparansi}

Transparansi yaitu bagaimana

Puskesmas Betungan dapat menciptakan kepercayaan timbal balik antara pemberi pelayanan dengan masyarakat dengan cara memberikan informasi dan menjamin kemudahan dalam memperoleh informasi yang akurat. (Tjiptono, 2012) Adapun indikator transparansi yaitu I) tersedianya informasi yang memadai setiap proses penyelenggaraan pelayanan kesehatan di Puskesmas Betungan, 2) Kemudahan dalam mengakses informasi (bebas diperoleh dan tepat waktu), 3) tersediantnya papan pengumuman atau papan informasi tata cara mengakses pelayanan kesehehatan di Puskesmas Betungan. Berdasarkan hasil dari analisis hasil penelitian bahwa transparansi yang diterapkan di Puseksesmas Betungan Kota Bengkulu cukup maksimal, seperti tersedianya papan informasi tentang tata cara mengkases pelayanan kesehatan, sesuai dengan hasil wawancara dengan informan (7/5/2019) :

"Papan informasi tata cara memperoleh pelayanan kesehatan disini sudah tersedia, kemudahan dalam memperoleh ya relatif, kalau seperti kami orang tua pastinya membaca dipapan pengumananlinformasi kalau web saya kurang tau apakah sudah ada atau belum"

Pelayanan Kesehatan di Puskesmas Betungan Kota Bengkulu merupakan pelayanan yang banyak digunakan oleh masyarakat karena merupakan pelayanan yang menjadi kebutuhan pokok masyarakat di daerah Betungan Kota Bengkulu. Munculnya permasalahan pada pelayanan kesehatan di Bengkulu Kota Bengkulu yaitu dikarenakan beberapa aspek yang harus dibenahi dengan memperbaiki tata kelelola pelayanan kesehatan di Puskesmas Betungan, salah satunya 
sistem informasi pelayanan berbasis web sehingga dapat diakses oleh masyarakat dimana saja, tidak harus melihat papan informasi yang disediakan di Puskesmas. Harapanya ketika masyarakat datang ke Puskesmas, masyarakat telah paham sebelumnya bagaimana proses memperoleh pelayanan dan berapa biaya yang harus disediakan oleh masyarakat. Sesuai hasil wawancara dengan informan (8/5/2019) :

"Informasi yang kami sediakan masih manual, belum berupa sistem informasi pelayanan kesehatan berbasis elektronik, kalau di sistem informasi kesehatan yang teritegrasi di e-kes masih berupa data Puskesmas Betungan bukan berupa prosedur pelayanan, SOP, biaya".

Berikut ini sistem informasi kesehatan

berbasis e-kes yang terintgrasi pada Dinas Kesehatan Provinsi Bengkulu :

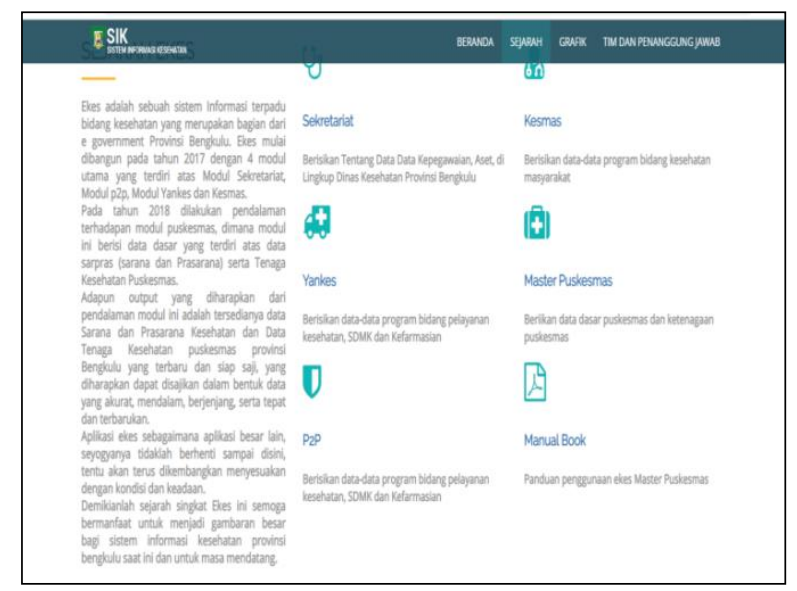

Gambar.I. Website E-Kes Provinsi Bengkulu

Sesuai dengan Peraturan Presiden Nomor 95

Tahun 2018 tentang Sistem Pemerintahan Berbasis Elektronik (SPBE) untuk mewujudkan tata kelolah pemerintahan bersih, efektif, transparan, dan akuntanbel (RI, 2018). Seharusnya SPBE ini telah diterapkan oleh Puskesmas Betungan selaku penyedia pelayanan publik, guna menciptakan pelayanan prima di Puskesmas Betungan Kota Bengkulu, hanya saja penerapan E-Kes ini belum maksimal sehingga belum dapat meningkatkan kualitas pelayanan kesehatan di Puskesmas Betungan. Penerapan E-Kes di Puskesmas Kota Bengkulu belum maksimal karena masih terdapat permasalahan pada sumber daya manusia, infrastruktur, dan masih lemahnya kolaborasi antar stakeholders (Triyanto \& Efendi, 2019).

\section{2) Responsivitas}

Responsivitas merupakan sikap aparatur pemerintah yang cepat dan tanggap dalam menyelesaikan tuntutan masyarakat dalam pelayanan publik, meliputi indikator yaitu I) tersediannya layanan pengaduan dan kotak saran.

2) tersedianya prosedur pengaduan masyarakat.

3) tersedianya standar pelayanan minimalis di Puskesmas. (Syardiansah, 2019) Berdasarkan dari analisis hasil penelitian bahwa sudah diterapkan cukup maksimal, yaitu tersedianya standar pelayanan minimalis, hanya saja tidak disediakan layanan pengaduan dan kotak saran untuk masyarakat yang komplain terhadap pelayanan yang diberikan oleh aparatur pelayanan Puskesmas. Sejalan dengan hasil wawancara informan (6/5/2019) :

"Menurut saya yang belum ada disini yaitu layanan pengaduan baik itu secara langsung maupun lewat telpon, dan tidak tersedianya kotak saran, biasanya kalau di bagian pelayanan kotak saran itu selalu tersedia, mungkin itu yang perlu diperbaiki kedepan"

Puskesmas Betungan Kota Bengkulu sebagai penyedia pelayanan harus menerapakan prinsip responsivitas yang baik dengan memiliki daya tanggap terhadap pengaduan masyarakat berdasarkan pelayanan yang diberikan oleh Puskesmas Betungan dengan cara menyedikan pelayanan pengaduan baikitu secara manual atau online dan kotak saran guna memperbaiki pelayanan kesehetan di Puskesmas Betungan. Sejalan dengan Peraturan Presiden Nomor 95 Tahun 2018 tentang Sistem Pemerintahan Berbasis Elektronik (SPBE) untuk mewujudkan tata kelolah pemerintahan bersih, efektif, transparan, dan akuntanbel (RI, 20I8).

"kedepan kami telah mengagas untuk pembuatan website Puskesmas Betungan supaya 
masyarakat mudah mengkases pelayanan di Puskesmas kami, di sana nanti kami sediakan pengaduan berbasis online sehingga masyarakat dapat komplain disana apabila pelayanan yang diterima kurang baik". (7/5/2019)

Penerapan prinsip responsivitas pada pelayanan kesehatan di Puskesmas Betungan Kota bengkulu belum berjalan dengan optimal masih terdapat kekurangan dibeberapa indikator yang belum terpenuh, untuk memperbaiki ini perlunya komitmen Puskesmas dan stakeholder terkait untuk meyedikan sarana prasarana yang masih kurang memadai salah satunya website Puskesmas Betungan Kota Bengkulu.

\section{3) Efektivitas dan Efisiensi}

Efektivitas dan efisiensi adalah setiap proses kegiatan dan kelembagaan diarahkan untuk menghasilkan sesuatu yang benar-benar sesuai dengan kebutuhan melalui pemanfaatan sumber daya yang tersedia, meliputi : I) terlaksananya admiistrasi penyelenggara pelayanan yag berkualitas dan tepat sasaran dengan didukung suimber daya yang optimal. 2) adanya monitoring dan evaluasi untuk memperbaiki kualitas pelayanan yang ada. 3) tidak adanya tumpang tindih pegawai (Triyanto, 2017). berdasarkan analisis hasil penelitian bahwa prinsip efetivitas dan efisiensi dalam pelayanan kesehatan di Puskesmas Betungan Belum optimal dikarena beberapa hal seperti masih lamanya waktu tunggu pelayanan, masih berbelit-belit tidak satu pintu masih terdapat loket-loket.

"Saya baru 2 kali kesini, yang pertama dulu saya mengurus surat keterangan sehat, yang sekarang berobat memang yang tidak bikin nyaman ini atrinya menurut saya harus adanya proses pemangkasan birokrasi sehingga pelayanan cepat dan tepat sasaran" (4/8/2019).

Efetivitas dan efesiensi pelayanan kesehatan selalu menjadi momok di Indonesia terkususnya di Puskesmas Kota Bengkulu karena pelayanan yang masih mempertahankan gaya lama (manual) selalu bermasalah pada antrian dan berbelit-belit, oleh sebab itu perlunya pengembangan elektronik kesehatan di Puskesmas guna memperbaiki kualitas pelayanan kesehatan yang cepet, tepat, transparan dan akuntabel (Mahsyar, 2014).

"Sebagai aparatur disini kami tentunya berharap pelayanan ini cepat dan tepat sesuai dengan harapan masyarakat, hanya saja regulasi atau SOP yang ada belum mendukung untuk hal itu, e-kes sudah ada tapi belum emnyentuh kesana untuk saat ini hanya berupa data informasi saja, harapan kesedapan Dinas Kesehatan Provinsi dan Kota melakukan sinergisitas untuk hal itu" (8/8/2019).

Salah satu inovasi pelayanan publik di Puskesmas Betungan salah satunya yaitu melakukan kolaborasi dengan Dinas Kesehatan Provinsi dan Kota Bengkulu untuk mengoptimalkan pelayanan kesehatan bebrbasi e-kes yang telah dibuat oleh Dinas Kesehatan Provinsi Bengkulu, hal tersebut juga sejalan dengan Peraturan Presiden Nomor 95 Tahun 2018 tentang Sistem Pemerintahan Berbasis Elektronik (SPBE) untuk mewujudkan tata kelolah pemerintahan bersih, efektif, transparan, dan akuntanbel (RI, 20I8). Untuk menerapkan pelayanan publik bebrbasis digitas perlu adanya kolaborasi yang baik dimana menerapkan kepercayaan dan komitmen antar stakeholders terlibat (Harmiati, Alexsander, Triyanto, Maya, \& Riastuti, 2020).

\section{KESIMPULAN}

Penerapan prinsip good governance dalam pelayanan kesehatan di Puskesmas Betungan Kota Bengkulu telah diteapkan cukup maksimal seperti : prinsip transparansi pada pelayanan kesehatan di Puskesmas Betungan Kota Bengkulu diterapkan cukup maksimal telah tersedianya papan informasi yang jelas mengenai tata cara mengases pelayanan, hanya saja masih berupa papan informasi yang ada di Puskesmas belum berbasib elektronik yang dapat diakses oleh 
masyarakat secara meluas. Prinsip responsivitas tpada pelayanan kesehatan di Puskesmas Betungan juga telah diterapkan cukup maksimal karena telah memiliki standar pelayanan minimalis (SPM), hanya saja belum tersedianya layanan pengaduan dan kotak saran untuk pengguna pelayanan. Selanjutnya prinsip efektivitas dan efisiensi telah diterapkan cukup maksimal karena Puskesmas Betungan telah melakukan monitoring dan evaluasi guna memperbaiki kualitas pelayanan yang ada, namun masyarakat pengguna pelayanan belum merasakan pelayanan prima karena pelayanan masih lama dan berbelit-belit.

\section{UCAPAN TERIMA KASIH}

Penulis mengucapkan terima kasih kepada tim peneliti yang telah banyak membantu sehingga penelitian ini selesai dengan baik. Kepada LPPM Universitas Prof Dr Hazairin SH yang selalu suport kepada kami untuk tetap produktif dibidang penelitian dan publikasi.

\section{REFERENSI}

Angkat, K. M., Kadir, A., \& Isnaini. (2017). Analisis Pelayanan Administrasi Kependudukan pada Dinas Kependudukan dan Pencatatan Sipil Kabupaten Dairi. Jurnal Administrasi Publik: Public Admnistration Journal, 7(15), 33-48.

Creswell, J. W. (2014). Research Design (Pendekatan Kualitatif, Kuantitatif, dan Mixed). Yogyakarta: Pustaka Pelajar.

Dwiyanto, A. (20I5). Manajemen Pelayanan Publik: Peduli, Inklusif, dan Kolaboratif (2nd ed.). Yogyakarta: Gadjah Mada University Press.

Harmiati, Alexsander, Triyanto, D., Maya, M., \& Riastuti, F. (2020). ANALISIS PEMETAAN COLLABORATIVE GOVERNANCE DALAM PROGRAM KELUARGA BERENCANA DI KOTA BENGKULU. Mimbar: Jurnal Penelitian Sosial Dan Politik, 9(I). https://doi.org/https://doi.org// 0.32663/jpsp.v9il

Johnson, R. R. (20II). Officer Attitudes and Management Influences on Police Work Productivity. Am J Crim Just, 36, 293-306. https://doi.org/ I0.1007/s I 2 103-0 10-9090-2

Mahsyar, A. (20I4). The Interaction Model Between Street-Level Bureaucrats and the Public in Health Service Provision at Puskesmas.
International Journal of Administrative Science \& Organization, 2 I (I), 44-48.

RI, P. PERPRES REpublik Indonesia Nomor 95 Tahun 2018 (2018).

Sugiyono. (2010). Metode Penelitian Kualitatif Kualitatif Dan R \& D. Bandung: ALFABETA.

Syardiansah. (2019). Analisis Indeks Kepuasan Masyarakat terhadap Pelayanan Publik Pada Pusat Kesehatan Masyarakat Langsa Barat. Jurnal Administrasi Publik: Public Admnistration Journal, 9(I),

68-74. https://doi.org// 0.3 I 289/jap.v9il .2255

Teguh, A. (20II). Memahami Good Governance Dalam Perspektif Sumber Daya Manusia. Indonesia: Gava Media.

Tjiptono, F. (20I2). Service Managemen Mewujudkan Pelayanan Prima. Jakarta: Andi.

Triyanto, D. (2017). ANALISIS KINERJA ORGANISASI DALAM MEWUJUDKAN PELAYANAN PRIMA KEPADA MASYARAKAT (Studi Pada Kantor Badan Pelayanan Perizinan Terpadu Kota Semarang). MIMBAR: Jurnal Penelitian Sosial Dan Politik, 6(4). Retrieved from https://journals.unihaz.ac.id/index.php/mimbar

Triyanto, D., \& Efendi, S. (2019). Analisis Penerapan Elektronik Kesehatan ( E-Kes ) di Puskesmas Rawat Inap Kota Bengkulu. Jurnal Administrasi Publik: Public Admnistration Journal, 9(2), I58-165. https://doi.org/http://dx.doi.org/ I0.3 I 289/jap.v9i2 .2901

Witanti, W., \& Abdillah, G. (20I8). Sistem Informasi Pelayanan Kesehatan Sebagai Upaya Peningkatan Kinerja E-Government. In Seminar Nasional Sistem Informasi Indonesia (pp. 222-228). 